\title{
THE PUBLIC OPINION ON THE DETRIMENTAL EFFECTS OF DEPLETED URANIUM AND THE EFFECTS OF THE BOMBING OF SRY (1999) IN SERBIA TODAY
}

\author{
Prof. dr Nada M. Sekulić* \\ University of Belgrade, Faculty of Philosophy
}

*nsekulic@f.bg.ac.rs 



\title{
THE PUBLIC OPINION ON THE DETRIMENTAL EFFECTS OF DEPLETED URANIUM AND THE EFFECTS OF THE BOMBING OF SRY (1999) IN SERBIA TODAY
}

\begin{abstract}
The bombing of Yugoslavia in 1999 has raised controversial questions concerning its legitimacy, justification, efficacy, and its impact on the health of Serbia's citizens. A striking lack of a clear and unambiguous common scientific attitude concerning the impact and harm of employing DU weapons, together with the absence of a clear political and legal attitude of international and national institutions, have been stirring up public opinion for decades, magnifying the ambiguity in dealing with this extremely important issue. It is obvious that, without sufficient and reliable research into the long-term impact of bombing with DU munitions, it will be very difficult to shape a grounded and plausible international policy concerning the usage of depleted uranium weapons. Moreover, it will provoke conflicts and increase 'the public fog' making it impossible to present an objective scope of damage and prove or refute the argument that DU weapons should be banned.

In the case of the Federal Republic of Yugoslavia, almost 20 years after the bombing, the Serbian government established a Commission aimed at estimating the overall impact of DU 'bombing' of Serbia. During these two decades, the chances of a thorough and continual monitoring of the citizens and areas which had been exposed to DU were missed, in spite of the fact that the bombing of the FRY was the first case in which NATO had been forced to publicly confirm their usage of DU munitions.

The paper addresses the following question: How is public opinion built in the absence of reliable data? The theoretical background in this approach is based on the theories of public opinion which assume that "individuals turned to the media to help themselves define social reality." (Moy \& Bosch, 2013). This means that public opinion, particularly public opinion on controversial issues which are not presented in a transparent and objective way, is built on stereotypes framed by political assumptions and affinities, without making a clear distinction between facts and preferences.

The paper presents the results of an online survey conducted on the sample of 534 Serbian citizens, in which we tried to use the above-mentioned approach as a hypothesis and to operationalize and prove it. The results show that attitudes toward the harmful effects of DU munitions depend greatly on the respondents' political affinities for the East or the West and their views on how the Kosovo crisis should be resolved. It also correlates significantly to their positive/negative identification with the Serbian national identity.
\end{abstract}

Keywords: depleted uranium, military operation "Noble Anvil", public opinion on NATO bombing of FRY 


\section{Introduction}

The use of DU in the "Noble Anvil" military operation in Yugoslavia in 1999 has raised very controversial questions concerning its legitimacy, justification, efficacy, and its impact on the health of Serbia's citizens. A striking lack of a clear and unambiguous common scientific attitude concerning the impact and harm of employing DU weapons, together with the absence of a clear political and legal attitude of international and national institutions, have been stirring up public opinion for decades, magnifying the ambiguity in dealing with this extremely important issue. It is obvious that, without sufficient and reliable research into the long-term impact of employing DU munitions, it will be very difficult to shape a grounded and plausible international policy concerning the issue. Moreover, it will provoke conflicts and increase 'the public fog' making it impossible to present an objective scope of damage and prove or refute the argument that DU weapons should be banned.

Besides presenting controversial data on this issue, based on representative reports (UNEP, nuclear experts from Vinča, ICBUW, USA National Report), the paper deals with the following question: How is public opinion formed in the absence of reliable data? The theoretical background in this approach is based on the theories of public opinion which assume that, rather than turn to media primarily for truth or information, "individuals turned to the media to help themselves define social reality." (Moy \& Bosch, 2013) This means that public opinion, particularly public opinion on controversial issues which are not presented in a transparent and/or objective way, is built on stereotypes framed by political assumptions and affinities, without making a clear distinction between facts and preferences.

The paper presents the results of an online survey conducted on the sample of 534 citizens of Serbia, in which we tried to use the above-mentioned approach as a hypothesis and to operationalize and prove it. The results show that the attitude toward the harmful effects of DU munitions depend greatly on the respondents' political affinities for the East or the West and their views on how the Kosovo crisis should be resolved. It also correlates significantly to their positive/negative identification with the Serbian national identity.

On May 18, 2018, nearly twenty years after the NATO military intervention against the FRY, the government of Serbia established a special commission tasked with estimating the effects of the usage of depleted uranium (DU) during the "Noble Anvil" military operation. During these two dec- 
ades, the chances of a thorough and continual monitoring of the citizens and areas which had been exposed to DU were missed, in spite of the fact that the bombing of the FRY was the first case in which NATO had been forced to publicly confirm their usage of DU munitions.

In the absence of a clear strategy and action plan of the state, which would provide information about the facts, various kinds of controversial information have emerged in the media estimating the scope of the ecological disaster produced by DU weapons. The issue of carcinogenic effects of the DU has been particularly controversial, as has that of whether there has been a disproportionate increase in malignancies in Serbia over the past two decades. Media statements were given by experts and laypeople - politicians, media stars, doctors, NGO activists, lobbyists, lawyers, public figures - often called to public attention in sensationalist talk shows, which provided little explanatory information of cognitive, military-political or ethical concerns. Disturbing images of public debates and the unpleasant situations created among the guests on these shows increased the ratings of these programs, but did little to contribute to the development of an objective and impartial journalism.

Before "Noble Anvil", DU ammunition had been used in Iraq and Afghanistan, raising similar controversial public issues that persist to date, and one of these cases - that of Italian soldiers deployed in Kosovo who had not been informed about protection measures during the employment of DU weapons, a number of whom subsequently developed cancer - ended up in court and was settled in favor of the affected soldiers. (Telegraf. co.uk, December 14, 2017; BBC News, Wednesday, 10 January 2007). ${ }^{1}$

It is very difficult for laypeople to follow experts' arguments for and against the issue, and the purpose of this paper is not to present 'the ultimate truth' about DU. However, it is obvious that each of the explanations about the damaging effects of DU, particularly those related to its carcinogenic effects, emphasize different DU aspects that the other side undervalues, while the facts stemming from scientific research are often similar.

In such a context, the public are not provided with enough sources and an open social platform to develop a rational and cognitive approach to the issue.

1 http://www.telegraf.rs/english/2919524-new-disturbing-data-comes-from-italy-348-soldiers-diedfrom-depleted-uranium-on-kosovo-and-metohija, retrieved on 9/8/2018; http://news.bbc.co.uk/2/hi/ europe/6247401.stm, retrieved on 9/8/2018 


\section{How much do we know about the detrimental effects of DU munitions?}

Uranium $(\mathrm{U})$ is a radioactive substance which exists in different forms (isotopes). It is naturally present in food and water at levels which are not considered harmful to human health. DU is a by-product of the enrichment process, aimed at the production of nuclear fuel and nuclear weapons. Unlike the enriched portion, in which isotope U235 is increased, DU has decreased the level of U235 and increased the level of U238. It is a very dense and very cheap substance, which is mainly why it is used in penetrator missiles. It can easily penetrate tanks and armor vehicles. As it penetrates a target, DU creates small particles that can be inhaled or ingested by those in close proximity. Once inside, DU can produce a rapid toxicologic effect (mostly on the kidneys) and a more slowly-evolving radiologic effect (mostly on the lungs and lymph nodes). DU emits $\alpha, \beta$ and $\gamma$ radiation, easily oxidizes producing highly toxic elements, and must be disposed of under special regime. Due to the oxidation, it is necessary to change the containers in which it is stored from time to time.

Here we present the essential findings and recommendations of two politically opposing international actors: the U.S. Department of Defense with the U.S. Military ("Review of the Toxicologic and Radiologic Risks to Military Personnel from Exposures to Depleted Uranium During and After Combat" (2008); "Depleted Uranium Aerosol Doses and Risks: Summary of U.S. Assessment" / Capstone Report/) (2005)), and the International Coalition to Ban Uranium Weapons ("Malignant Effects: Depleted Uranium as Genotoxin and Carcinogen") (2014), Manchester: ICBUW.

These two reports have been chosen since they show in comparative perspective common facts and divergent strategies of interpreting the facts. These two reports represent two poles, which, juxtaposed, send contradictory messages concerning DU, despite the fact that they are based on the same sort of research data. Consequently, the public have no recourse than to form their opinions in the absence of an unambiguous, complete and distinctive scientific picture of the harmful effects of DU. 


\section{Review of the toxicologic and radiologic risks to military personnel from exposures to depleted uranium during and after combat}

The report was conducted by the National Research Council as per the requirements of the U.S. Department of Defense. It represents a revision of the key and most representative US military report "Depleted Uranium Aerosol Doses and Risks: Summary of U.S. Assessment" (Capstone Report) (2005), conducted as a result of public concern about health issues among veterans and civilians exposed to DU.

In the framework of both of these (merged) reports, the examination of toxicologic and radiologic effects of the usage of DU weapons involved only US soldiers (fewer than 104 of those exposed to DU were due to the misidentification, which led to a series of friendly fire incidents) and was focused only on selected issues - renal effects, acute effects and alpha radiation. Research on the civilian population in endangered war-affected areas was not conducted, and the purpose of the report was only to estimate risks to USA combatants. The Review (2008) promotes the usage of DU munitions because of their high-density and self-sharpening effects, both of which better penetrate armor, a fact which, according to the Review, helped bring the operation "Desert Storm" to a swift and very successful completion. The Review is considered public data, but the draft manuscript has remained confidential. None of the independent experts engaged in compiling the report was allowed to give any recommendation or endorse any conclusions, nor could they see the report before it was released.

The assessment of the detrimental impact of DU was made in controlled experimental conditions outside the actual war-affected areas. They were based on shooting DU munitions into fighting vehicles and measuring samples of air in the vehicles in order to detect concentrations of DU. A mathematical biokinetic model was applied to a previously conducted research on US soldiers in order to establish the relationship between possible human intake and possible organic damage. Independent research on humans was not conducted in the framework of the Review and the effects of a possible prolonged exposure were basically not assessed, although the report emphasizes the importance of such data and recommends that future reports should be improved in that direction ${ }^{2}$. The study states that

2 The influence of a prolonged exposure to DU is of essential importance, since prolonged exposure can induce health issues even if levels of DU are minimal. For example, the key US military report (Capstone Report, 2005), considers the dose of $2.2 \mu \mathrm{g} / \mathrm{g}$ of renal uranium concentration as completely safe, 
current research on risk of cancer and chronic diseases following exposure to DU is inadequate, since chromosomal mutations of the exposed human population have given mixed results and the latent period associated with radiation-induced cancer can be 10 years or even much longer. Their estimation of the radiologic risk to soldiers exposed to DU was based only on the acute effects and only on measuring alpha radiation.

Concerning the broader available research data used in the report, it derives from previous research on animals and humans, mostly conducted in peacetime and, as for the research on humans specifically, it was carried out on mine workers who had been exposed to higher amounts of natural radioactive substances such as uranium, radium and radon in their line of work. The report confirms that it has been proved (particularly in controlled experiments with animals) that uranium, as well as DU, can cause mutations, cell transformation and DNA strand breaks in both in vivo and in vitro studies. Its genotoxic effects are based on both chemical and radiologic effects. However, current research data and scientific achievements do not allow of conclusive proof as to whether concrete cases of cancer (except in controlled experimental situations) are caused by uranium and particularly by DU or some other unknown cause or exposure, since the mechanisms whereby uranium produces various injuries to the cells are not fully understood.

The cumulative and intersectional effects of toxicologic and radiologic effects were not examined.

The general conclusion of the report is that current research data is not proof enough of a correlation between DU munitions and cancer cases. The report does not state anything about whether DU munitions should be banned, but suggests (at the beginning) that its usage, besides military reasons related to penetration force and precision, contributes to shortening the period of armed activity and war duration.

Recommendations:

1. Assessment of risk from cancer posed by military exposure to DU is characterized by a lack of research data relating to the mechanism of how DU induces malignant changes. It is necessary to conduct additional animal studies with DU oxide particles similar to those produced during the Gulf War.

2. Co-exposure to other carcinogen materials in tanks should be added

while chronic exposure to DU can cause renal health issues even at the level of $0.1 \mu \mathrm{g} / \mathrm{g}$ (Review of the Toxicologic and Radiologic Risks to Military Personnel from Exposures to Depleted Uranium During and After Combat, 2008). Ten years after exposure to DU, US soldiers showed urinary uranium concentrations indicating that DU had been permanently (p. 21) absorbed into their bodies. 
to the calculation of DU carcinogenicity.

3. It is necessary to revise the definition of the upper and lower limits of renal uranium concentrations recognized as dangerous/safe. The Army should avoid setting definite values before further research.

4. Risks to personnel who were outside the tanks (zone II and III of the risk) should also be calculated and measures of protection defined more precisely.

\section{The "malignant effects: depleted uranium as genotoxin and carcinogen" report conducted by the international coalition to ban uranium weapons}

The report begins by stating that the use of DU munitions appears to be intrinsically unacceptable to most people and that they should be subsumed under the category of inhumane and unacceptable weapons which should be banned. The difficulty of establishing a scientifically proven causal link between its use and its humanitarian impact requires a different approach and different standards to those that have been applied to other explosive weapons. Owing to scientific complexity and uncertainty, the Coalition call for the application of Precautionary Principle as the most useful model for judging the usage of DU in military interventions. They consider precaution a necessary model whenever there is a possibility of causing serious harm to human health and the environment. The report tries to simplify scientific terms in order to make it understandable to the public. It was written with the purpose of presenting data which corroborates the detrimental effects of DU and helping to ban DU weapons.

It is emphasized at the beginning of the report that it is not always possible to show scientifically the mechanisms whereby DU damages cells, even though biomarkers show that genotoxic effects have occurred. This is why it is extremely difficult to prove in real-life situations that carcinogenic diseases are causally linked to DU and not to other possible causes, many of which are outside controlled experimental surroundings.

As in the Review of the Toxicologic and Radiologic Risks to Military Personnel from Exposures to Depleted Uranium During and After Combat, the ICBUW report presents various kinds of scientific data that confirm DU-linked malignant cell transformation, chromosomal change, generation of DNA strand breaks, oxidative damage, genomic instability, all of which affect human lung and bone cells the most. It emphasizes that the 
International World Health Organization's (WHO) Agency for Research on Cancer classifies DU as carcinogenic not only because of its toxicologic (chemical) characteristics, but also because of the radiation it emits.

The main issue this report raises is that there are not enough studies on the civilian population living in the environs of the sites contaminated by DU which would prove that whole areas are carcinogenic rather than only the very locality where DU rounds hit the target. Due to a lack of data, it is not possible to quantify risks precisely, which is extremely important, since DU weapons were used in populated areas and near drinking water sources. It emphasizes that desk research and mathematical modeling are not sufficient proof that DU does not produce considerable risks to human health.

Recommendations:

1. Full disclosure of targeting data

2. Determine the extent of civilian exposure

3. Precaution must guide munitions development

4. Ban uranium weapons

The common points between both reports (the National Research Council Review and the UCBUW Report) are that DU is a dangerous and carcinogenic material, both toxicologically and radiologically. However, it is not possible to follow the mechanisms of its mutagenicity to the body, which invalidates evidence in all the cases of cancer that appear in non-experimental surroundings. The defined upper and lower limits of DU caused by radiation are found to be either overestimated or underestimated in the National Research Council Review (conclusions of the report), whereas the "Malignant Effects" Report, arguing in favor of a precautionary approach, considers all doses of DU (exposed in an uncontrolled manner, such as explosions) dangerous. Both reports require further research.

The former sees no reason to restrain from further usage of DU munitions, while the latter calls for an immediate ban.

\section{A case study of the FRY - Vinča Institute report and UN Report}

Here we present two reports related to the usage of DU weapons in NATO military intervention against the FRY in 1999. The first is the UN report and the second is an independent analysis carried out by several 
experts from Vinča Institute of Nuclear Sciences, which served, in addition to military experts reports, as the main source of FRY internal assessments of the radiation levels and toxicity of the weapons deployed during and immediately after the military intervention. It is important to mention that almost all the sites where missiles had been discovered were cleared by FRY expert teams before UNEP experts started their field research. The "Operation Noble Anvil" (US term) or "Operation Allied Force" (EU term) or "Milosrdni anđeo" (Merciful Angel) (Serbian term, which become the main code name for the intervention among the citizens of FRY) lasted from $24^{\text {th }}$ March 1999 to $1^{\text {st }}$ June 1999. The intervention was halted once the army and government of the FRY agreed to withdraw their forces from Kosovo, leaving the region open to the establishment of an independent Kosovo government and the (still ongoing process of) independence of the Republic of Kosovo. The intervention was shortly followed by the deposition of Slobodan Milošević and Serbia embarked on a process of capitalist transition. The NATO admitted to having used DU weapons and published maps of the targeted areas only after being placed under the pressure of the UN. The FRY was the first country where deployment of DU weapons had been publicly acknowledged. It is still debatable whether these maps and data represent a precise and complete picture of DU weapons usage in the intervention against the FRY. DU weapons have also been used in Afghanistan and Iraq.

UNEP report - findings:

1. The UNEP could not find any significant contamination on the ground surface of the soil except at localized points of direct contamination (the holes around penetrators). DU levels detected at those penetrations points (research conducted at points of impact) decreased around the holes and were not detectable beyond one meter from the holes. Laboratory analyses of soil show contamination several meters around the penetration points. Since DU contamination was found in all soil samples, it could be concluded that there was widespread contamination of the soil. However, contamination levels were below standard risk levels to human health. Radiologic and chemical risks were found to be insignificant.

2. Uncontaminated areas can be a source of serious risk to human health, but only through leakage to groundwater, contamination of plants, and inhalation. However, the detected dose was so low that the report does not consider the danger significant unless one should come into direct contact with the oxidized penetrator. According to 
the report, danger does not arise from radiation, but from metal toxicity.

3. There is a danger of beta radiation only as a result of one's prolonged exposure to the penetrator (for example, if they should keep pieces of missiles as a trophy).

4. Penetrators buried in the ground, if dispersed in water or dug out, can be dangerous (dispersion of DU can be much higher and faster than that of natural uranium). The gradual increase in uranium concentration in water is estimated (calculated, which does not mean that it was actually measured on the ground) to be possibly higher than that proposed by WHO health standards.

5. No significant risks of DU in water and air was found during field research. DU was detectable in the air samples, but in acceptable doses according to health standards.

6. No contamination of plants was found.

7. The report makes it clear that the research was conducted on a small sample, since most of the penetrators were not found at the moment when research was being conducted, assuming that they are most probably buried deep in the ground.

\section{Independent Report of Experts from Vinča Institute of Nuclear Sciences: DU in the Aggression Against the FRY}

The title of the independent report of the experts from Vinča Institute is quite different to that of the UNEP report. The former is entitled "Depleted Uranium in NATO Aggression Against Yugoslavia", while the latter is couched in much more neutral terms: "DU in Serbia and Montenegro: Post-conflict Environmental Assessment in the FRY". These titles generally reflect their considerably different political views of the 'bombing' ${ }^{3}-$ on the one hand as aggression, implying that the purpose of the report is to show the scope of the aggressor's responsibility for the unlawful attack on a sovereign state and people, and on the other hand, in a rather understated manner, as an 'environmental' issue, implying that the intervention itself has resolved the conflict ('post-conflict' issues). The titles show that neither is politically neutral and that they were shaped by different purposes and perspectives on what really had happened and how it unfolded. Their scientific findings suit and serve different political agendas, regardless of their scientific content.

3 Here we use the popular term 'bombing. DU weapons include air, naval weapons and ground artillery. 


\section{Findings:}

1. The report emphasizes that the aggression was indiscriminate, targeting civil and military facilities, industrial objects, cities, roads, electric, oil and chemistry industry, plants, causing leaking of various toxic and carcinogenic substances from different sources into the environment. The report points out at the very beginning that the aggressor used bombs filled with silver oxide and ammunition with DU (classifying it under the category of extraordinarily dangerous weapons), causing permanent pollution in the country.

2. It emphasizes that DU is a radioactive material some of whose isotopes (such as U235) contain relatively low proportions of natural uranium, a point often stressed by the proponents of its military usage, while others (such as U238) contain extremely high proportions. The enriched isotopes are much higher than the International Basic Safety Standards defines as safe.

3. The report suggests that the dispersion of DU during bombing is underestimated, since standards define 'safe' doses in controlled situation and/or marked surroundings. In case of bombing, there is no such thing as a marked area of dispersion, but only a marked area of 'safe' detection. Consequently, continual exposure to low ('safe') doses of DU was not estimated properly.

4. A meticulous radiologic measuring of the terrain carried out by a team of experts from Vinča Institute at the sites of NATO bombing did not yield traces of DU radioactive contamination. The soil was contaminated but soon after the bombing was over the areas where penetrators were found were thoroughly cleared and the measuring did not show radiation levels above accepted 'safe' levels, which should be acutely dangerous. The low levels of contamination in some zones (South Serbia) are due to the targets having been missed and the bullets having penetrated into soft soil. If the targets had been hit, there would have been a risk of heavy pollution. Higher contamination levels were detected only around the penetrators and the surrounding holes, with an astonishing presence of U238 and beta rays.

5. The team informs that they did not have access to the Kosovo area and so have no data for that region, which was the epicenter of DU bombing.

6. They note that measurements of pollution should also include effects of the presence of dangerous materials from installations, industry, 
etc. and their mixture with DU missiles. These analyses show a presence of heavy ecological pollution. Many of these materials are carcinogenic themselves.

7. At 11 localities where UN team conducted their research, 8112 projectiles were fired. The UN team found only 48 . This begs the question of the whereabouts of all those poisonous penetrators. The question is of extreme importance, since penetrators are the epicenters of pollution.

8. Research on humans was not conducted at all and it should be included in a future monitoring of the terrain.

These reports have not been followed up by any examination of either terrain or the population, which should have been the duty of the FRY government. Some research was done in Vranje (near Pljackovica, an area that has not been completely decontaminated). Local medical staff published that 12 people died of cancer between 1995 and 2005. 21 children were born with a chromosome disorder in 1998, and as many as 73 in $2008^{4}$. In the Public Health Institute in Vranje, funds were appealed for in a bid to to make reliable statistical surveys on a sample of 6,000 people, but no support was received. The Ministry of Environmental Protection ordered local health institutions not to interfere with their work. However, in actuality, they were doing nothing concerning further investigations.

\section{How do people in Serbia form their opinion on the detrimental effects of DU?}

How is the public supposed to reconcile different, inadequate and conflicting messages, particularly those published in scientific and incomprehensible jargon? Generally, the reaction of the public is a collective one. Since the bombing affected the whole territory of Serbia, a large number of people continue to show a keen interest in this issue, particularly as it is related to life risks and serious health issues. Many people become involved in discussions, forming synergy in crowds (Ginneken, 2003), in which people's opinions, images and emotions converge in a rhythmic manner. The visible actors are political leaders, technical experts, reporters, who advocate favored interpretations, debate with their opponents, seek approval from the audience; however, the media audience proves to be an 'angrier'

4 http://www.novosti.rs/vesti/srbija.73.html:258682-Iznad-Vranja-brdo-smrti 
or more sympathetic mass recipient than the attentive, engaged and diverse public. The old theories of mass media implied that a mass audience was socially undifferentiated, lacking any clear division along class, sex, or race lines. It was simply a 'crowd' (Bennett, 1982: 30). But even some of the first theoreticians of mass opinion at the beginning of the $20^{\text {th }}$ century (Lippmann 1922, 1993/1925; Le Bon 2005) noticed that 'the mental unity' of the crowd does not actually imply that group identity is shaped by the object of public opinion. Just the opposite-class, gender, race and ethnicity are the sources of the public mobilization related to certain media contexts or messages (Ginneken, 2003: 84). Interestingly, during a two-decade debate on the detrimental effects of DU in Serbia, no alternative or diverse public approach has been developed, no visible and strong initiatives to ban DU have been established, and the public has gathered in two big blocks of (mostly angry) mass audience. All kinds of images, emotions and explanations came to resonate with these two big political blocks as their referent points. As Moy \& Bosch (2013) mentioned in their work on the theories of public opinion, individuals often did not resort to the media or any mass source of information seeking the truth. "Individuals turned to the media to help themselves define social reality", which means that the issue of social grouping and social belonging frequently goes beyond the need for facts and information. Moreover, following the pattern of the hierarchies of needs (Visser, 1998:84), the audience often start to equate with them, assuming that belonging to the 'right' group means 'knowing the truth', despite the fact that they have not formed their opinions based on a cognitive approach, but rather on political preferences, group consciousness and their trust in the preferred authorities. In such conditions, the object of public attention functions as a tool, or a medium, for social grouping, and the facts are used selectively, depending on how much they can serve concrete political agendas.

In such circumstances, the answers to 'burning' political questions (such as DU weapons) are somehow pregiven. That means, and this was the main hypothesis of this paper and of the online research presented in the next chapter, that opinions about the detrimental effects of DU probably depend more on the political grouping and affinities than on cognitive processes. One of the above-mentioned opposing political blocks is pro-NATO and the other anti-NATO, one of these blocks is 'nationalistic, the other 'European'.

In order to be marked as an 'attentive' and mindful audience, the public need to seek input relevant to the issue, develop different options, assess 
consequences, and, at best, be ready to become active in promoting the values and outcomes stemming from their choices. An 'attentive' public is a presumption of democracy since it puts public in the position of social actors. Otherwise, they are more exposed to manipulations and serve as passive support to political elites whose interests they represent.

\section{The online survey}

\section{The impact of public political preferences on attitudes about the detrimental effects of depleted uranium (DU) weapons}

The online survey was made on a sample of 534 respondents. The survey was publicly distributed on the Facebook social network during the summer of 2018 and was available until it was filled in by around 500 respondents. The only requirement was for respondents to be citizens of Serbia (including those with dual nationality, which constituted $3.8 \%$ of the sample). The data was not used to make generalizations, but with the preliminary purpose of examining the structure of responses, the interdependence between four groups of questions/topics: 1) attitudes of the respondents about the detrimental effects of depleted uranium, 2) political preferences of the respondents regarding the status of Kosovo, 3) political preferences for Western or Eastern countries/political blocks, 4) affirmative/negative attitudes toward Serbian identity and Serbian self-identification.

The main aim of this research was to examine if and to what extent public opinion on DU has been influenced by broader public political opinions and preferences.

The research has revealed a 'deep play' (Geertz, 2005) between opposing political groups/subjects, in which a cognitive issue (the detrimental effects of DU) becomes the stake in their public gaming/betting for social approval and support. This political battle has a form of 'all or nothing', since audience cannot bet on both of them and must choose only one political side/party. Just as with Balinese cocks in Geertz's story about the Balinese, here we have 'deep play' which transfers debate and bitter fight between political groups to a 'pseudo-cognitive' debate on DU, which also takes on the form of an 'all or nothing' discourse aimed at forcing one to choose between 'right' and 'wrong', which is a form of political betting .

Since most of the respondents $(83 \%)$ declared themselves as Serbian (9.9\% did not answer the question, 2.2\% declared themselves as Yugosla- 
vian, all the other options constituting a percentage of below 1\%), we could also interpret the data referring to the Serbian identity as positive or negative ethnic self- identification.

Descriptive analyses

1. Attitudes about the detrimental effects of depleted uranium (ADU)

This group of questions includes six statements, which are used as a composite variable defining the attitude of the respondents toward the detrimental effects of depleted uranium, with the emphasis on its carcinogenic effects. The list of offered responses in online questionnaire was longer, but these 6 items satisfied the requirements of consistency, homogeneity and normal distribution.

Table 1. Items of the composite variable: Attitudes about the detrimental effects of depleted uranium (with the emphasis on its carcinogenic effects), and the correlation matrix between them

\begin{tabular}{|c|l|c|c|c|c|c|}
\hline \multicolumn{1}{|c|}{ \% } & 1 & $\mathbf{2}$ & $\mathbf{3}$ & $\mathbf{4}$ & $\mathbf{5}$ \\
\hline 1 & $\begin{array}{l}\text { (I believe that) bombs with depleted uranium } \\
\text { cause cancer. }\end{array}$ & 8.4 & 5 & 17 & 20.8 & 49 \\
\hline 2 & $\begin{array}{l}\text { There is a lot of research and data that confirm } \\
\text { the devastating effects of depleted uranium, } \\
\text { but their publishing is obstructed. }\end{array}$ & 11.6 & 8 & 32.4 & 20.6 & 27.4 \\
\hline 3 & $\begin{array}{l}\text { In Serbia, there has been an extraordinary } \\
\text { increase in the incidence of cancer diseases due } \\
\text { to depleted uranium bombing. }\end{array}$ & 9.2 & 6.7 & 23.7 & 23.5 & 37 \\
\hline $\begin{array}{l}\text { It is high time the Serbian government formed } \\
\text { a commission to investigate the consequences } \\
\text { of NATO bombing in 1999. }\end{array}$ & 10.9 & 4.2 & 16 & 18.3 & 50.6 \\
\hline 5 & $\begin{array}{l}\text { R It has been scientifically proven that bombing } \\
\text { using depleted uranium does not cause cancer. }\end{array}$ & 46.1 & 9.9 & 31 & 5.1 & 7.8 \\
\hline & $\begin{array}{l}\text { R It is irresponsible to confuse people with } \\
\text { questions about depleted uranium twenty years } \\
\text { after the bombing. }\end{array}$ & 43.8 & 17 & 11.3 & 13 & 14.9 \\
\hline
\end{tabular}

$1=$ strongly disagree, $2=$ partially disagree, $3=$ none of the above, $4=$ partially agree, $5=$ strongly agree $\mathbf{R}=$ responses that required reverse scoring 
Correlation matrix (Pearson's):

\begin{tabular}{|c|c|c|c|c|c|c|}
\hline & 1 & 2 & 3 & 4 & 5 & 6 \\
\hline 1 & 1.00 & .684 & .793 & .610 & .686 & .558 \\
\hline 2 & .684 & 1.00 & .672 & .528 & .566 & .423 \\
\hline 3 & .793 & .672 & 1.00 & .615 & .630 & .537 \\
\hline 4 & .610 & .528 & .615 & 1.00 & .500 & .535 \\
\hline 5 & .686 & .566 & .630 & .500 & 1.00 & .504 \\
\hline 6 & .558 & .423 & .537 & .535 & .504 & 1.00 \\
\hline
\end{tabular}

Cronbach's alpha=0.893; Mean: .589; Min..423, Max..793; Kaiser-Meyer-Olkin Measure=.897; Bartlett's test of Sphericity (Sig.) $=.000$

The responses show that the majority of the respondents believe that DU bombs (i.e. munitions) have carcinogenic effects, meaning also, in accordance with their responses, that this has been the main cause of the increase in carcinogenic diseases in Serbia since 2000s. Most of them take a very serious view of the health issues caused by the 1999 bombing and think that the Serbian government still has a duty to investigate the case. The majority of them do not agree with the statement that it has been scientifically proven what exactly is the effect of DU bombing and believe that the publishing of data that question NATO's reports has been obstructed. In addition, only 6.7\% trust NATO's reports (NATO's reports do not confirm the carcinogenic influence of DU munitions). (Due to a lack of normal distribution, the last statement was unsuitable for inclusion in the composite variable and was analyzed as an independent variable - almost $80 \%$ 178.9\%/ of the respondents do not trust NATO's research and public data on nuclear weapons)

\section{Political preferences of the respondents regarding the status of Kosovo (AK)}

The composite variable was made up of eight statements which relate to the respondents' understanding of the political crisis in Kosovo and their vision of the solution to the problem. These eight statements proved to be consistent and suitable in all aspects for parametric analyses. The following table shows the respondents' choices and the correlation matrix between these eight statements. 
Table 2. Political preferences of the respondents regarding the status of Kosovo and the correlation matrix between them

\begin{tabular}{|c|c|c|c|c|c|c|}
\hline & $\%$ & 1 & 2 & 3 & 4 & 5 \\
\hline 1 & $\begin{array}{l}\text { Instead of being put behind bars for } \\
\text { organizing the bombing of the FRY, } \\
\text { Madeleine Albright and Wesley Clark are } \\
\text { buying mines and businesses in Kosovo. }\end{array}$ & 5.2 & 3.4 & 22.5 & 19.7 & 49.2 \\
\hline 2 & Kosovo is Serbia. & 16.8 & 8.2 & 14.3 & 11.9 & 48.8 \\
\hline 3 & $\begin{array}{l}\text { Attitudes of the Albanians toward the } \\
\text { monuments of Serbian medieval Orthodox } \\
\text { culture in Kosovo is reason enough for } \\
\text { Serbia not to recognize Kosovo. }\end{array}$ & 10.9 & 11.1 & 16.3 & 14.9 & 46.7 \\
\hline 4 & Kosovo - the heart of Serbia. & 25.1 & 10.2 & 17.8 & 12.3 & 34.7 \\
\hline 5 & $\begin{array}{l}\text { Concerning Serbian culture in Kosovo, the } \\
\text { Albanians are the same as the Taliban. }\end{array}$ & 8.2 & 7.3 & 18 & 16.1 & 50.5 \\
\hline 6 & $\begin{array}{l}\mathbf{R} \text { Whether you like it or not, the fact is that } \\
\text { Serbia has lost Kosovo. }\end{array}$ & 24.7 & 12.2 & 14.9 & 20.1 & 28.1 \\
\hline 7 & $\begin{array}{l}\mathbf{R} \text { Serbian property in Kosovo is lost. It is } \\
\text { best not to discuss it again. }\end{array}$ & 45.6 & 17.2 & 10.9 & 15.1 & 11.3 \\
\hline 8 & $\begin{array}{l}\mathbf{R} \text { Serbian generals who hide their } \\
\text { responsibility for killing Albanian civilians } \\
\text { in Kosovo do not have the legitimacy to } \\
\text { speak about the harmful consequences of } \\
\text { the FRY bombing. }\end{array}$ & 23.2 & 9 & 21.5 & 20.3 & 26.1 \\
\hline
\end{tabular}

$1=$ strongly disagree, $2=$ partially disagree, $3=$ none of the above, $4=$ partially agree, $5=$ strongly agree $\mathbf{R}=$ responses that required reverse scoring

\section{Correlation matrix (Pearson's):}

\begin{tabular}{|c|c|c|c|c|c|c|c|c|}
\hline & 1 & 2 & 3 & 4 & 5 & 6 & 7 & 8 \\
\hline 1 & 1.00 & .484 & .459 & .478 & .421 & .411 & .329 & .320 \\
\hline 2 & .484 & 1.00 & .704 & .775 & .458 & .654 & .618 & .469 \\
\hline 3 & .459 & .704 & 1.00 & .650 & .422 & .523 & .498 & .385 \\
\hline 4 & .478 & .775 & .650 & 1.00 & .394 & .620 & .549 & .507 \\
\hline 5 & .421 & .458 & .422 & .394 & 1.00 & .328 & .289 & .318 \\
\hline 6 & .411 & .654 & .523 & .620 & .328 & 1.00 & .657 & .468 \\
\hline
\end{tabular}




\begin{tabular}{|c|c|c|c|c|c|c|c|c|}
\hline 7 & .329 & .618 & .498 & .549 & .289 & .657 & 1.00 & .398 \\
\hline 7 & .320 & .469 & .385 & .507 & .318 & .468 & .398 & 1.00 \\
\hline
\end{tabular}

Cronbach's alpha: .883; Mean: .485, Min. 289, Max.775; Kaiser-Meyer-Olkin Measure=.902; Bartlett's test of Sphericity (Sig.) $=.000$

The list of the offered responses related to Kosovo was longer, but not all of them could be included in the composite variable. Some of these responses show that the majority of respondents have almost identical opinions on certain issues $-81.7 \%$ of the respondents do not agree with the attitude that Serbs got what they deserved in Kosovo, 79.4\% think that the Albanians are conducting a preplanned cultural genocide of Serbians in Kosovo, and $65.2 \%$ are against the recognition of the Kosovo state.

The indicators included into the common variable cover the issue of Serbian war crimes in Kosovo, the issue of Serbian property in Kosovo, the Albanian destruction of Orthodox heritage and Serbian culture in Kosovo, and attitudes about the independence of Kosovo.

\section{Political preferences for Eastern/Western political allies (AEW)}

We combined eight indicators into a single variable measuring the respondents' political preferences for the East or the West. Conceptually and statistically, this variable also proved to be consistent and suitable for further analyses. It encompassed a range of offered statements concerning Serbia's potential membership in the EU, its military cooperation with Russia, positive or negative attitudes toward Germans/Russians, and affinity for public figures such as the Russian president Vladimir Putin. All the offered statements were designed to measure solidarity with, affinity for, and political assessment of the East or the West, and the ideas about what kind of military alliances would be best for Serbia's future. 


\section{Table 3. Political preferences for Eastern/Western countries and the correlation matrix between them}

\begin{tabular}{|c|c|c|c|c|c|c|}
\hline & $\%$ & 1 & 2 & 3 & 4 & 5 \\
\hline 1 & $\begin{array}{l}\text { The construction of a Russian military base } \\
\text { near Niš should be allowed. }\end{array}$ & 29 & 10.3 & 21.4 & 12.6 & 26.7 \\
\hline 2 & The Russians are our brothers. & 24.9 & 12.6 & 21.8 & 18.4 & 22.2 \\
\hline 3 & EU leaders do not want a strong Serbia. & 11.7 & 9.8 & 20.3 & 16.5 & 41.8 \\
\hline 4 & Putin is king. & 30.6 & 10.1 & 20.5 & 14.3 & 24.5 \\
\hline 5 & $\begin{array}{l}\text { The Germans have always been our } \\
\text { enemies. }\end{array}$ & 21.2 & 19.7 & 23.9 & 15.7 & 19.5 \\
\hline 6 & $\begin{array}{l}\text { If Serbia needs a military ally, Russia should } \\
\text { be it. }\end{array}$ & 23.4 & 9.8 & 20.9 & 18.4 & 27.4 \\
\hline 7 & $\begin{array}{l}\text { It is better for Serbia to cooperate more with } \\
\text { the East than the West. }\end{array}$ & 18.4 & 12.8 & 34.5 & 16.5 & 17.8 \\
\hline 8 & R Serbia should become part of the EU. & 33.6 & 14.8 & 13.4 & 16.5 & 21.7 \\
\hline
\end{tabular}

$1=$ strongly disagree, $2=$ partially disagree, $3=$ none of the above, $4=$ partially agree, $5=$ strongly agree $\mathbf{R}=$ responses that required reverse scoring

\section{Correlation matrix (Pearson's):}

\begin{tabular}{|c|c|c|c|c|c|c|c|c|}
\hline & 1 & 2 & 3 & 4 & 5 & 6 & 7 & 8 \\
\hline 1 & 1.00 & .697 & .435 & .705 & .451 & .686 & .628 & .400 \\
\hline 2 & .697 & 1.00 & .475 & .775 & .491 & .747 & .638 & .406 \\
\hline 3 & .435 & .475 & 1.00 & .451 & .406 & .496 & .430 & .457 \\
\hline 4 & .705 & .775 & .451 & 1.00 & .446 & .736 & .650 & .431 \\
\hline 5 & .451 & .491 & .406 & .446 & 1.00 & .538 & .446 & 388 \\
\hline 6 & .686 & .747 & .496 & .736 & .538 & 1.00 & .770 & .524 \\
\hline 7 & .628 & .638 & .430 & .650 & .446 & .770 & 1.00 & .516 \\
\hline 7 & .400 & .406 & .457 & .431 & .388 & .524 & .516 & 1.00 \\
\hline
\end{tabular}

Cronbach's alpha: .905; Mean: .543, Min..388, Max.775; Kaiser-Meyer-Olkin Measure=.911; Bartlett’s test of Sphericity (Sig.) $=.000$ 


\section{The Serbian identity - positive/negative identification}

In addition, the questionnaire included one battery of statements referring to positive/negative orientation toward the Serbian identity and its main symbols. Since the responses to these statements do not have normal distribution, we used only several of them as independent variables and analyzed them using the nonparametric HI- test.

Table 4. Positive/negative attitudes toward the Serbian identity

\begin{tabular}{|c|l|c|c|c|c|c|}
\hline & $\%$ & 1 & 2 & 3 & 4 & 5 \\
\hline 1 & The Cyrillic script is obsolete. & 75.1 & 9.6 & 6.9 & 4.2 & 4.2 \\
\hline 2 & $\begin{array}{l}\text { Sometimes I feel embarrassed } \\
\text { because I am from Serbia. }\end{array}$ & 58.4 & 10.2 & 6.1 & 13.2 & 12.1 \\
\hline 3 & $\begin{array}{l}\text { People in Serbia are primitive and it } \\
\text { will take a long time for us to reach } \\
\text { the European level of culture. }\end{array}$ & 36.3 & 14.9 & 13.6 & 20.7 & 14.5 \\
\hline 4 & $\begin{array}{l}\text { When I am abroad I do not like } \\
\text { the people to know I come from } \\
\text { Serbia. }\end{array}$ & 79.3 & 8.4 & 5.2 & 3.4 & 3.4 \\
\hline
\end{tabular}

$1=$ strongly disagree, $2=$ partially disagree, $3=$ none of the above, $4=$ partially agree, $5=$ strongly agree

\section{Parametric analyses and the $\chi^{2}$ test}

The aim of this part of the analysis was to show the extent to which attitudes toward DU (composite variable ADU) are determined by the respondents' political orientations/preferences (composite variable AEW, $\mathrm{AK}$ ) and whether the attitude toward DU bears any relationship to positive/negative Serbian ethnic self-identification.

Multiple regression was applied to three composite variables - ADU (Attitudes toward the detrimental effects of depleted uranium) as a dependent variable, and AEW (Political preferences for Eastern/Western countries and the correlation matrix between them) and AK (Political preferences of the respondents regarding the status of Kosovo) as predictors. 
The analyses show strong correlations between these three variables:

Table 5. Correlations between composite variables ADU, AK and AEW

\begin{tabular}{|c|l|c|c|c|}
\hline & & $1 \mathrm{ADU}$ & $2 \mathrm{AK}$ & 3 AEW \\
\hline 1. & ADU (Attitudes toward DU) & 1.00 & .673 & .623 \\
\hline 2. & AK (Attitudes toward Kosovo) & .673 & 1.00 & .768 \\
\hline 3. & $\begin{array}{l}\text { AEW (Attitudes toward Eastern/Western } \\
\text { Allies) }\end{array}$ & .623 & .768 & 1.00 \\
\hline
\end{tabular}

Parson's corr. Sig. 000

Since correlations between AK and AEW were too high (above 0.700), implying that these two composite variables measured almost the same thing, they were merged into one variable. The new composite variable (AK/AEW) correlates strongly with the dependent variable AK (0.690). The assumption of normality, multicollinearity and homogeneity of variance was not violated. The regression model explains $47.6 \%$ of variance $\left(\mathrm{R}^{2}=.476\right.$; Sig.000), which means that the analyses confirmed a strong influence of the respondents' political preferences on the attitudes about the detrimental effects of DU. This means that we can predict public attitudes toward DU by learning their political preferences concerning the political resolution of the Kosovo crises, or concerning their preferences for certain political alliances. The fact that somebody strongly supports the independence of Kosovo or argues in favor of NATO allies can be interpreted as predictors of their attitudes to the toxicologic and radiologic effects of DU.

In addition, using HI-square analyses, the interconnection between ADU (Attitudes toward the detrimental effects of DU) and Serbian positive/negative self-identification was measured. The analyses confirm a significant connection $(\mathrm{p}<0.05)$. The increase of negative attitudes toward Serbian self-identification was proportionate to the decrease in negative attitudes toward the detrimental effects of DU. The respondents with a negative Serbian self-identification are exactly those who share the attitude that DU is not related to cancer and that its detrimental effects are low. This pattern was confirmed comparing all the measured statements (table 6) 
Table 6. Interconnection (Hi-square measurement) between positive/negative attitudes toward Serbian identity (self-identification) and ADU (attitudes toward the detrimental effects of DU)

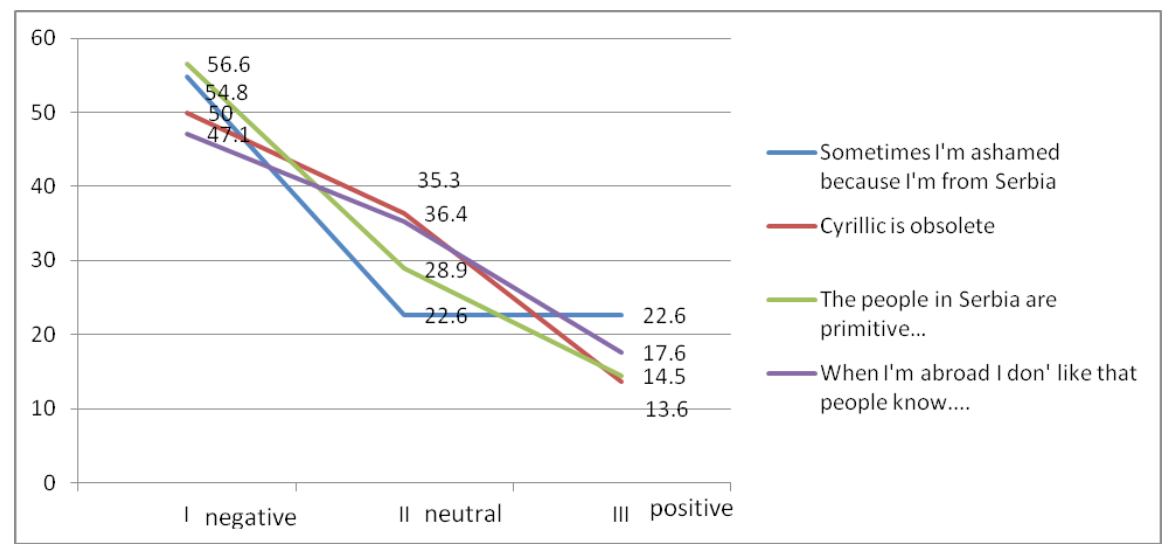

$-=$ negative

$+=$ positive

$\mathrm{N}=$ neutral

\begin{tabular}{|l|c|c|c|c|}
\hline \multicolumn{1}{|c|}{$\%$} & - & $\mathrm{N}$ & + & $\chi^{2}$ \\
\hline The Cyrillic script is obsolete. & 50 & 36.4 & 16.3 & $\begin{array}{c}\chi^{2}=54.99, \text { Sig.000 } \\
\text { Cramer's V=.230 }\end{array}$ \\
\hline $\begin{array}{l}\text { Sometimes I feel embarrassed because I am } \\
\text { from Serbia. }\end{array}$ & 54.8 & 22.6 & 22.6 & $\begin{array}{c}\chi^{2}=45.23, \text { Sig.000 } \\
\text { Cramer's V=.209 }\end{array}$ \\
\hline $\begin{array}{l}\text { When I am abroad I do not like people to } \\
\text { know I come from Serbia. }\end{array}$ & 47.1 & 35.3 & 17.6 & $\begin{array}{c}\text { Sig.002, Cramer's } \\
\text { V=.154 }\end{array}$ \\
\hline $\begin{array}{l}\text { People in Serbia are primitive and it will } \\
\text { take a long time for us to reach the European } \\
\text { level of culture. }\end{array}$ & 56.6 & 28.9 & 14.5 & $\begin{array}{c}\chi^{2}=47.07, \text { Sig.000, } \\
\text { Cramer's V=.213 }\end{array}$ \\
\hline
\end{tabular}

\section{Conclusion}

In this paper we presented some of the controversial issues related to the detrimental effects of DU weapons, showing that even experts and representative institutions do not share the same views on the necessity to ban DU weapons, and do not recommend the same strategies related to social and health policies, even in warring zones. While some of them (U.S. Ministry of Defense) argue in favor of the continuation of its usage or main- 
tain that DU is harmless (Canadian Ministry of Veterans' Affairs), others call for an immediate ban on DU weapons (International Coalition to Ban Uranium Weapons). Some treat it as part of conflict resolution (UNEP report on the usage of DU in the FRY) and others as a source of long-term ecological disaster (Vinča Institute report). While some of them rely on short-term research, small samples, experimental examination, others emphasize the necessity for a long-term monitoring in 'natural' settings, call for research on humans in the contaminated areas, and require a cumulative and intersectional approach. In some of the conducted research only alpha radiation was measured, while in other studies all the aspects of radiation were measured (alpha, beta, gamma), and it was stressed that their presence in nature was not comparable with the DU composition. It is very difficult even for educated laypeople to follow their arguments and strategies of data interpretation, sometimes 'cunningly' presented to the public (Pavlović, 2001).

If there is such a thing as a simple answer to the question of how dangerous DU is, then part of the universally accepted answer is that DU is a dangerous radioactive and toxicologic substance which must be kept under strictly controlled conditions and that there is not still enough data (and research) on its prolonged detrimental effects on the civil population in the areas where DU weapons were used. There is evidence in a great deal of controlled experimental research conducted on animals that DU can cause cancer and serious organic damage, but it is still not well known which mechanisms connect them. Because of that, it is very difficult to prove that the cases of cancer or illness occurring in war-affected zones where DU has been used are the causal effects of DU bombing.

Showing the complexity of this issue, we tried to examine some of the aspects of public opinion dynamics present in the debate on DU. Relying on the theories of public opinion that favor the public need for social and political grouping over the need for knowledge, we developed a pilot instrument to measure whether this kind of grouping is present in public opinion on DU in Serbia. The analyses show a strong influence of the need for social grouping on public attitudes toward the detrimental effects of DU, which is basically a cognitive issue.

The conclusion of the paper is that the public atmosphere related to the debate on this issue is favored by the social dynamics of the 'psychological crowd, which is the mark of mass culture and society, albeit not of a democratic, attentive and cognitive media audience, provoking conflicts and increasing 'the public fog' in which it will not be possible to present the 
objective scope of damage and develop beneficial and responsible political strategies.

\section{References}

Bennet T. (1982). "Theories of Media, Theories of Society". In: Gurevitch M. (ed.): Culture, Society and the Media, London: Methuen

Bon Le G. (2005): Psihologija gomile, Beograd: Algoritam

Parkhurst, M., Szrom, F., Guilmette, R., Holmes, T., Cheng, Y. S., Kenoyer, J. L., ... \& Beckman, J. C. (2004). Capstone Depleted Uranium Aerosols: Generation and Characterization (No. PNNL-14168). Pacific Northwest National Lab.(PNNL), Richland, WA (United States).

Infante-Rivard, C. (2013). Depleted Uranium and Canadian Veterans: A Review of Potential Exposure and Healh Effects.

UNEP, (2002). Depleted Uranium in Serbia and Monte Negro. Post-Conflict Environmental Assessment in the Federal Republic of Yugoslavia. Switzerland

Evert P., Isernia P. (eds.) (2001). Public Opinion and the International Use of Force. London, New York: Routledge

Geertz, C. (2005). Deep play: Notes on the Balinese cockfight. Daedalus, 134(4), 56-86.

Ginneken van J. (2003). Collective Behaviour and Public Opinion, Mahwah, New Jersey, London: Lawrence Erlbaum Associates Publ.

Institute of Medicine. (2008). Gulf War and Health. Committee of Gulf War and Health, Washington: The National Academy Press

Laswell H.D., Blumenstok D. (2006). World Revolutionary Propaganda, San Francisco: Alfred A. Knopf

Liolios, T. E. (2000). Assessing the risk from the depleted uranium weapons used in Operation Allied Force. Science \& Global Security, 8(2), 163-181.

Lippmann W (1922). The Public Opinion, New York: Harcout

Lippmann W.(1993/1925). The Phantom Public, New Brunswick, London: Transaction Publishers

Malignant Effects: depleted uranium as a genotoxin and carcinogen. (2014). ICBUW (International Coalition to Ban Uranium Weapons), Manchester: ICBUW

Moy P., Bosch B. (2013). Theories of public opinion. Sociology Department. Faculty Publications. 244, University of Nebraska- Lincoln

Orlic M. (2000). "Osiromaseni uranijum kao produkt nuklearne tehnologije", XLIV konferencija za ETRAN, Sokobanja 26-29. jun.

Pavlović R, Pavlović S., Šipka D., Todorović D., Paligorić D., Radenković M., Đuric J. (2001): „Osiromaseni uranijum u agresiji NATO na FRJ”, rad saopsten na seminaru: „Osiromaseni uranijum - istine i zablude”, jun, Beograd, Hem.ind. 55: 7-8, 309-317.

Petković S., Zarić M., Dević Z. (2001). Upotreba municije sa osiromasenim uranijumom u agresiji NATO na FRJ”. Rad saopsten na seminaru: „Osiromaseni uranijum - istine i zablude, jun, Beograd, Hem.ind. 55: 7-8, 318-324. 
Review of Toxicologic and Radiologic Risks to Military Personnel from Exposure to DU During and After Combat. (2008) National Research Council, http://www.nap.edu/ catalog/11979.html, Retrieved on 9/8/2018.

Visser M. (1998). Five Theories of Voting Actions, Twente University Press

Facts on Depleted Uranium (2001). papers submitted to the conference. Prague. https://inis.iaea.org/collection/NCLCollectionStore/_Public/34/083/34083234.pdf Retrieved on: 9/8/2018

\title{
ОДНОС ЈАВНОГ МЊЕЊА У СРБИЈИ ПРЕМА ШТЕТНИМ ПОСЛЕДИЦАМА ОСИРОМАШЕНОГ УРАНИЈУМА И ПОСЛЕДИЦАМА БОМБАРДОВАЊА СРЈ 1999. ГОДИНЕ
}

\author{
Нада М. Секулић, редовни професор, \\ Универзитет у Београду, Филозофски факултет
}

\begin{abstract}
Резиме
Бомбардовање Југославије 1999. године изазвало је контроверзна питања везана за легитимност, оправдање сврхе, ефикасност и утицај на здравље грађана Србије. Упечатљив недостатак јасног и недвосмисленог заједничког научног става о утицају и штетности употребе оружја са осиромашеним уранијумом (DU - depleted uranium), као и недостатак јасног политичког и правног става међународних и националних институција, деценијама су подстицале јавно мњење, повећавајући двосмислености у решавању овог изузетно важног питања. Очигледно је да ће, без довољног и поузданог истраживања о дугорочном утицају бомбардовања са овим оружјем, бити веома тешко обликовати утемељену и веродостојну међународну политику у вези са употребом оружја са осиромашеним уранијумом. Штавише, то ће изазвати конфликте и повећати „јавну маглу” у којој неће бити могуће представити објективни обим штете и неће бити могуће доказати или одбацити ако се оружје са осиромашеним уранијумом забрани. У случају Савезне Републике Југославије, скоро 20 година након бомбардовања, српска влада је успоставила Комисију са циљем процене укупног утицаја бомбардовања Србије са DU. Током ове две деценије, изгубљене су шансе да се грађани и подручја која су била изложена DU темељно и континуирано прате, упркос чињеници да је бомбардовање СРЈ било први случај у коме је НАТО био принуђен да јавно потврди употребу муниције са DU.

Рад се бави питањем: Како је изграђено јавно мњење у одсуству поузданих података? Теоријска позадина у овом приступу заснива се на теоријама јавног мњења које претпостављају да се "појединци не окрећу медијима примарно због истине или информација, они се окрећу медијима како би сами себи дефинисали друштвену стварност" (Моу\& Bosch, 2013). То значи да је јавно мњење, а посебно јавно мишљење о контроверзним питањима која нису представљена на транспарентан и објективан начин, изграђена на стереотипима уоквиреним политичким претпоставкама и афинитетима, без јасне разлике између чињеница и преференција.
\end{abstract}


У раду је приказан резултат онлајн анкете спроведене на узорку од 534 грађана Србије, у којој смо покушали да користимо горе поменути приступ као хипотезу и да је операционализујемо и докажемо. Резултати показују да став о штетном утицају оружја DU у великој мери зависи од политичке склоности испитаника према Истоку или Западу и њихових погледа на то како би требало решити кризу на Косову. Такође је снажно повезана са њиховом позитивном / негативном идентификацијом са српским националним идентитетом.

Кључне речи: осиромашени уранијум, војна операција „Племенити наковањ”, јавно мњење о НАТО бомбардовању СРЈ 